\title{
Öğretmen Seçme ve Atama Uygulaması Olarak Kamu Personeli Seçme Sınavına
}

\section{(KPSS) İlişkin Öğretmen Adaylarının Algıları}

\section{Hasan Basri MEMDUHOĞLU*， Mehmet Fatih KAYAN***}

Öz:Bu araştırmanın amacı, Kamu Personeli SeçmeSınavı (KPSS) ve alan sınavına yönelik öğretmen adaylarının görüşlerinin incelenmesidir. $\mathrm{Bu}$ çalışmada amaçlı örnekleme yöntemlerinden ölçüt örnekleme kullanılmıştır. Araştırma, 12'si Yüzüncü Yıl Üniversitesi Eğitim Fakültesinin de öğrenim görmekte olan ve 4'ü de fen-edebiyat fakültesi öğrencisi/mezunu olup pedagojik formasyon eğitimi almakta olan toplam 16 öğretmen adayı ile yürütülmüştür. Öğretmen adaylarının 6’sı kadın, 10’u ise erkektir. Araştırmada nitel araştırma desenlerinden olgu bilim deseni kullanılmıştır. Öğretmen adaylarının KPSS olgusuna ilişkin algıları ortaya konulmaya çalışıldığı için olgu bilim deseninin bu araştırmanın amacına uygun olduğu düşünülmektedir. Çalışmanın verileri yarı yapılandırılmış görüşme tekniğiyle toplanmıştır. Literatür taramasının yanı sıra uzman görüşlerine başvurularak hazırlanan görüşme formu araştırmacılar tarafından geliştirilmiştir. Görüşme formu 7 adet açı uçlu sorudan oluşmaktadır. Görüşmelerde elde edilen ses kayıtları doküman haline getirilmiş ve betimsel analiz tekniği kullanılarak analiz edilmiştir. Katılımcıların görüşlerini çarpıcı bir şekilde yansıtmak amacıyla sık sık doğrudan alıntılara yer verilmiştir. Çalışma bulgularına göre KPSS'ye alan sınavının dâhil edilmesi öğretmen adaylarının tümü tarafından olumlu karşılanmıştır. Öğretmen adayları, KPSS’nin öğretmenlik becerilerini ölçmede yetersiz kaldığını düşünmektedirler. Buna rağmen öğretmen adayları, ülkemiz şartlarında KPSS tarzı bir sınav ile atamaların yapılmasını en makul yöntem olarak görmektedirler.

*Doç. Dr. Yüzüncü Yıl Üniversitesi, Eğitim Fakültesi, Van, orcid.org/0000-0001-5592-2166, hasanbasri@yyu.edu.tr

Ö̈̈̆r.Gör. Yüzüncü Y1l Üniversitesi, Eğitim Fakültesi, Van, orcid.org/0000-0002-4702-4080, kayanfatih@yahoo.com 
Anahtar Sözcükler:Öğretmen yetiştirme, öğretmen seçimi, öğretmen adayları, KPSS, alan Sinav1

\section{Pre-Service Teachers' Perceptions of Selection and Assignment Regarding to Civil Servant Selection Examination (CSSE)}

Abstract: The aim of this study is to reveal the pre-service teachers' opinions on Civil Servant Selection Examination (CSSE) and field examination. In this study, criteria sampling has been used which is a purposeful sampling method. The study has been conducted with total of 16 pre-service teachers. 12 of whom were students at the Yüzüncü Y1l University Education Faculty and the other 4 participants were students/bachelor from Faculty of Science and Faculty of Humanities and were attending the pedagogical formation certificate program. Six of the participants were female and others were male. In the study, phenomenological design was used which is a qualitative research design. It is believed that the phenomenological design is appropriate for the purpose of this research because the preservice teachers' perceptions of CSSE occurrences were tried to be revealed. The data of the study were collected by semi-structured interview technique. The interview form has been developed by the researchers by referring to expert opinion sand by searching the literature. The interview form consists of seven openended questions. The voice recordings obtained in the interviews were documented and analyzed by using descriptive analysis technique. Direct citation was often used in order to reflect the views of the participants strikingly. According to the findings of the study, the inclusion of the field examto CSSE was welcomed by all of the participants. Pre-service teachers think that CSSE is in adequate to measure the teaching skills. Nevertheless, thepre-service teachers regard the CSSE examination as the most reasonable method in ourcountry'sconditions. 
Keywords:Teacher training, teacher selection,pre-service teachers, KPSS,field examination

\section{Giriş}

Eğitim, toplumların kalkınma çabalarında önemli rol oynar. Çünkü eğitim bir toplumun sosyal ve ekonomik kalkınması için öncelikle ihtiyaç duyulan nitelikli insan gücünün yetiştiricisidir (Bowen, 1980, akt. Gedikoğlu, 2005). Toplumsal gelişme için eğitim siteminin tüm yönleriyle ve bileşenleriyle iyi işlemesi önemli bir zorunluluktur (Çapa ve Çil, 2000).Eğitim sisteminin en önemli bileşenlerinden biri öğretmendir. Bu noktada eğitim sistemin etkili işleyişi ve belirlenen amaçlara ulaşması bakımından pedagojik formasyonu yeterli, konu alanına hâkim ve işini severek yapan öğretmenlere ihtiyaç vardır.

Öğretmenler, öğrenciler ve öğretim programları olarak üç temel saç ayağı üzerine oturan eğitim sisteminin niteliğinin arttırılmasında en önemli unsurun öğretmen olduğu belirtilmektedir (Şişman, 2011; Çapa ve Çil, 2000). Eğitim sisteminde yeralan öğretim programları, kullanılan materyaller ve fiziki koşullar ne kadar iyi olursa olsun işini severek yapan ve alanında uzman öğretmenlere sahip olunmadan istenilen başarıyı yakalamanın imkânsız olduğu kabul edilmektedir. Eğitimde kalite; akıllı tahta, akıllı tabletten çok nitelikli öğretmenlerle sağlanabilir. Bu bağlamda öğretmenniteliğinin temel belirleyicilerinin başında gelen öğretmen yetiştiren kurumlara öğrenci kabulü, hizmet öncesi eğitim ve mesleğe atanmaölçütlerinin okullarda verilen eğitimin kalitesi açısından büyük öneme sahip olduğu ifade edilebilir.

Türkiye'de öğretmen yetiştiren kurumların temelini oluşturan ve öğretmen yetiştiren ilk kurum olarak sayılan Darulmualliminin kurulmasından bugüne kadar(Unat, 1964, akt. Taşdan, 2011) özellikle Cumhuriyet döneminde çok farklı öğretmen yetiştirme uygulamaları hayata geçirilmiştir. İlköğretmen okulları, köy muallim mektepleri, eğitmen kursları, köy enstitüleri, öğretmen liseleri, eğitim enstitüleri, eğitim yüksekokulları ve eğitim fakülteleri 
öğretmen yetiştirmek üzere kurulan okullardan bazılarıdır (Öztürk, 1999). Ayrıca yedek subay öğretmenlik uygulaması (1960), vekil öğretmenlik (1961), öğretmenlik formasyonu (1970), mektupla öğretmen yetiştirme (1974), hızlandırılmış öğretmen yetiştirmeprogramları (1975), askerliğini öğretmen olarak yapma (1987), her türlü yüksek öğretim programından mezun olanlar için hiçbir koşul aranmaksızın öğretmen atanması (1996) gibi uygulamalar da eğitim tarihimizdeki ilginç ve tartışmalı öğretmen yetiştirme uygulamalarından bazılarıdır (Eraslan, 2006).

Görüldüğü üzere,Cumhuriyetin ilanından bütün öğretmen yetiştirme kurumlarının eğitim fakültesi bünyesinde toplandığı 1993 yılına kadar farklı öğretmen yetiştirme politikaları benimsenmiş ve farklı uygulamalara gidilmiştir. Öğretmen yetiştirme politikalarımızın sürekli bir şekilde değişmesi çağı yakalama gayreti, yeni kurulmuş bir ülke olmanın eğitim alanında doğurduğu olumsuzluklar ve öğretmen yetiştirmenin zorluğu gibi nedenlere bağlanabilir.

\section{Öğretmen Yetiştirme Sürecinde Aday Seçimi}

Öğretmen yetiştirme,öğretmen adaylarının seçimi, hizmet öncesi eğitimleri, bu süreçteki staj uygulamaları ve hizmet içi eğitimi gibi birçok farklı boyuttan oluşan oldukça kapsamlı bir alandır (Kavcar, 2002). Bu boyutları birbirini izleyen boyutlar olarak ele aldığımızda ilk sıraya öğretmen adaylarının seçimini koymakgerekeceği kabulünün yaygın bir kabul olduğunu söylemek yanlış olmayacaktır. Diğer boyutların sağlıklı yürümesi için öncelikle öğretmen adaylarının doğru şekilde seçilmesigerektiği söylenebilir.

Öğretmen adaylarının seçiminde iyi bir öğretmende olması gereken özelliklerve öğretmenyeterlikleri ön plana çıkmaktadır. "İyi bir öğretmen”kavramı ile ilgili olarak yapılabilecek birçok farklı tanım arasından Bandura (1969)'nın yaptığı ‘öğretmen kişilik nitelikleri ve bu niteliklerin çocukların zihinsel, duygusal ve sosyal gelişimi üzerine 
muhtemel etkilerine dayanan hâlihazırdaki mevcut bir psikolojik güçtür” (akt. Sünbül, 1996)tanımı“iyi öğretmen” tanımlamalarının çoğunu kapsaması bakımından önemlidir. İyi bir öğretmende bulunması gereken özellikler Kavcar (2002) tarafından mesleki ve kişisel özellikler olarak ikiye ayrılmıştır. Kavcar'ın (2002) mesleki özellikleri alan bilgisi, genel kültür ve öğretmenlik meslek bilgisi olarak ifade ettiği yeterlikler aynı zamanda 1739 sayılı Milli Eğitim Temel Kanununda (METK) belirtilen yeterliliklerdir. Kavcar (2002)kişisel özellikleri ise kişinin mesleğe yatkınlığı, öğretmenliğin gerektirdiği örnek olma ve model olma şeklinde ifade etmiştir. Karaca (2008) ise öğretmen yeterliğini “öğretmenin mesleği ile ilgili iş ve görevlerini yapabilme gücü, yeteneği ya da öğretmenin sahip olması gereken nitelikler" olarak tanımlamıştır.

Öğretmenin sahip olması gereken mesleki becerilerin eğitimle öğretmen adaylarına aktarılmasındaki yapılabilirlik, adayın kişisel özelliklerinin geliştirilmesinde mümkün olmayabilmektedir. İşini severek yapma, öğretmenlik mesleğinin kutsallığına olan inanç, öğrencilerine bir ebeveyn şefkatiyle yaklaşma gibi öğretmenlerin sahip olması gereken kişisel özelliklerin öğretmenlik eğitimi ile öğretmen adaylarına aktarılması kolay değildir.Bu durum öğretmen yetiştiren kurumlarda öğrenci kabulünü daha önemli bir hale getirmektedir. Kişisel özelliklerin eğitim sürecinde kazandırılmasının zorluğu dikkate alındığında bu özelliklere sahip kişilerin öğretmen adayı olarak seçilmesi önem kazanmaktadır. Nitekim öğretmenlik bir sevgi işidir ve bu alanda görev yapacak bireylerin bilişsel becerilerinin yanı sıra duyuşsal becerilerinin de sınanması,üstlenecekleri zorlu ve önemli görevin hakkını verebilecek öğretmenlerin yetiştirilmesi bakımından önemlidir.

Ülkemizde öğretmen adaylarının seçiminde kullanılan merkezi sınav sistemi adayların kişisel yeterliklerini ölçme bakımından yetersiz kalmaktadır. Bu durum işini severek ve inanarak yapabilecek birçok adayı dışarıda bırakabilmekte, öğretmenlik mesleği ile arasında hiçbir duygusal bağ bulunmayan ve sadece kolay bir şekilde atanabileceğini düşündüğü için 
bu mesleğe yönelen bireyleri sisteme dâhil edebilmektedir. Bu gerçeklerden yola çıkarak öğretmen adaylarının kabul sürecinin özelliklede duyuşsal becerilerinin ölçülmesinin ne derece önemli olduğu daha iyi anlaşılabilir.

1998 yılında Yüksek Öğretim Kurulu, Milli Eğitim Bakanlığı ve Dünya Bankası işbirliği ile gerçekleştirilen 'Hizmet Öncesi Öğretmen Eğitimi Projesi’ dâhilinde öğretmen yetiştirme programları yeniden yapılandırılmıştır. Türkiye'deki öğretmen eğitimi standartlarını uluslararası standartlar seviyesine taşımayı amaçlayan bu proje ile birlikte getirilen birçok yenilikten biride öğretmen adaylarının seçiminde ‘öğretmenlik mesleğine yönelik olarak yeterli düzeyde istekli olması'nın göz önünde bulundurulmasıdır (Erdem, 2013; Adıgüzel, 2008). Ancak projenin bu ayağı uygulamaya konulamamış, kişisel özellikleri belirleme imkânı olmayan merkezi sınav sistemi ile öğretmen adaylarının seçimine devam edilmiştir.

\section{Öğretmen Atamaları ve KPSS}

Geçmiştebazı dönemlerde ülkemizde öğretmen yetiştirme programlarından mezun olan adayların atamaları koşulsuz bir şekilde gerçekleşmekteydi. Öğretmen yetiştirmede arztalep dengesinin ortadan kalkması mezun öğrencilerin birçoğunun atanamaması problemini de beraberinde getirmiştir. Özellikle son y1llarda üniversitelerden mezun olan öğretmen adaylarının MEB'in ihtiyacının ve tahsis edilen kadronun çok üzerinde olması (Karataş ve Güleş, 2012) öğretmen atamalarında kullanılan ölçme araçlarını üzerinde daha çok durulması gereken bir konu haline getirmiştir.

2015 yılı eylül ayında yapılan öğretmen atamasında MEB tarafindan ilan edilen 37.000 kadroya toplam 161.836 başvuru gerçekleşmiştir. Bazı bölümlerde açılan kadro sayısı ile bu kadrolara yapılan başvurular Tablo 1'deki gibidir. 
Tablo 1'de görüldüğü üzere başvuru sayıları, kadro sayılarının çok üzerindedir. Durum bazı bölümler için daha vahim bir hal almaktadır. Elemeye dâhil olan her 10 öğrenciden ancak bir veya ikisinin atanabildiği bölümler bulunmaktadır. Bu durum arz ve talep arasındaki dengesizlik ile açıklanabilir. Bunun yanında KPSS'ye girip taban puanı geçemediğinden ötürü başvuru yapamayan adaylar da göz önünde bulundurulunca arz ve talep arasındaki dengesizliğin çok daha vahim boyutlarda olduğunu görebiliriz.

Tablo 1. 2015 Yılı Branşlara Göre Öğretmen Atama Kadro ve Başvuru Sayıları

\begin{tabular}{lccc}
\hline Branş & Kadro sayısı & Başvuru sayısı & Başvuru oranı \\
\hline Beden Eğitimi & 1.176 & 7.315 & $\% 622$ \\
Biyoloji & 1.088 & 6.338 & $\% 582$ \\
Din Kült. ve Ahl.Bil. & 3.789 & 10.760 & $\% 283$ \\
Fen Bilimleri/Fen ve Teknoloji & 1.521 & 8.336 & $\% 548$ \\
İlköğretim Matematik Ö̆ğr. & 2.552 & 5.408 & $\% 211$ \\
İngilizce & 3.934 & 8.853 & $\% 225$ \\
Matematik & 1.322 & 9.427 & $\% 713$ \\
Okul Öncesi Öğrt & 2.072 & 11.782 & $\% 568$ \\
Özel Eğitim & 1.579 & 2.101 & $\% 133$ \\
Rehberlik & 1.427 & 4.395 & $\% 307$ \\
Sınıf Öğretmenliği & 4.157 & 13.309 & $\% 320$ \\
Türk Dili ve Edebiyatı & 1.077 & 11.861 & $\% 1101$ \\
Türkçe & 1.957 & 7.260 & $\% 370$ \\
\hline
\end{tabular}

Kaynak: www.memurlar.net

Günümüzde öğretmen yetiştirme işi YÖK'e bağlı kurumlar olan üniversitelerin eğitim fakültelerine verilmiş iken öğretmen atama görevi Milli Eğitim Bakanlığına bırakılmıştır. Dolayısıyla bu iki kurumun eşgüdüm içinde birlikte hareket etmeleri zorunluluk halini 
almaktadır (Nartgün, 2008). Milli Eğitim Bakanlığı ve YÖK arasında koordineli olarak yapılacak bir planlama ile arz-talep arasında makul bir denge kurulabileceği ve böylelikle öğretmen adaylarının mağdur edilmelerinin önünegeçilebileceği ifade edilebilir. Ancak bu konuda sorunların üstesinden gelebilecek düzeyde çalışma eksikliği hissedilmektedir.Akdemir (2013)'e görebu bağlamda yapılabilecek en tutarlı iş atama yapılırken ölçme araçlarının olumlu ve olumsuz yönleriyle değerlendirilmesi ve sağlıklı bir yöntemin kullanılmasıdır.

Ülkemizde geçmiş yıllarda uygulanan atama modellerini incelediğimizde ihtiyaçtan az kişinin öğretmenlik mesleğine başvuru yaptığı dönemlerde sınav şartının kaldırıldığı, ihtiyaçtan fazla kişinin başvuru yaptığı zamanlarda ise sınav sistemine geçildiğigörülmektedir (Eraslan, 2006). 1985 yılına kadar olan süreçte yetişmiş öğretmen yetersizliğinden dolayı atamalarda herhangi bir sınav yapılmamıştır. İlk olarak 1985-1991 yılları arasında ‘Öğretmen Yeterlilik Sınavı' adı ile uygulamaya konulan sinavlı eleme sistemine 1992 yılında son verilmiş ve tüm öğretmen yetiştirme kurumlarından mezun olan adayların yeterli nitelikleri taşıdığı kabul edilerek kura yöntemiyle atamalar yapılmıştır. Üniversitelerden mezun olan öğretmen adaylarının MEB'in ihtiyacının çok üzerinde olması nedeniyle 2001 yılında tekrardan sınavlı sisteme geçilmiştir. Bu doğrultudaÖSYM tarafından yapılmasına karar verilen 'Kamu Meslek Sınavı- KMS' uygulamaya konulmuş, daha sonraki yıl ise sınavın adı 'Kamu Personeli Seçme Sınav1- KPSS' olarak değiştirilmiştir (Yüksel, 2004).

1739 sayılı Milli Eğitim Temel Kanunu (1973)'nda belirtildiği üzere bir öğretmende bulunması gereken nitelikler; alan bilgisi ve becerileri, öğretmenlik meslek bilgisi ve becerileri vegenel kültürdür. YÖK (2007) tarafından gerçekleştirilen Eğitim Fakültesi Öğretmen Yetiştirme Lisans Programları'nın yeniden yapılandırılması çalışmasında alan bilgisi ve becerileri \%50, öğretmenlik meslek bilgisi ve becerileri $\% 30$ genel kültür ise $\% 20$ olarak oranlandırılmıştır. Bu oranlar ve ders saatleri öğretmenlik dallarına göre farklılık 
gösterebilmektedir (YÖK, 2007). Nitekim alan sınavının getirildiği 2013 yılına kadar KPSS'de öğretmen adaylarının alan bilgisi ve becerileri ölçülmemekteydi. Bu konuda yapılan eleştirileri göz önünde bulunduran ÖSYM 2013 yılı itibariyle öğretmen adaylarının mezun oldukları alan bilgisi ve becerilerine hitap eden ek bir sınavaKPSS'de yer vermeye başlamış ve değerlendirmede bu alana \%50’lik bir pay vermiştir.

Günümüzde öğretmen atamalarında kullanılan temelyöntem olan KPSS ve 2016 yılında öğretmen atama sürecine eklenen mülakat sınavı üzerine yapılan tartışmalar devam etmektedir. KPSS'ye yönelik tartışmaların odağındaki konu ise KPSS'nin nitelikli öğretmen seçiminde yeterli işleve sahip ve amaca uygun bir seçme uygulaması olup olmadığ sorunsalıdır.Nitelikli bir öğretmenin, öğrenciler ve toplum üzerindeki olumlu etkisini göz önünde bulundurduğumuzda KPSS'nin ülkemiz için ne denliöneme sahip bir sınav olduğunu anlayabilmekteyiz. Bu bağlamda KPSS üzerine yapılacak olan çalışmaların bu sınavın daha nitelikli hale gelmesine, nitelikli birKPSS'nin ise içinde bulunduğu çağın gereksinimlerini taşıyanbireylerin yetişmesinde başat rol oynayan nitelikli öğretmenlerin seçilmesinde, özellikle karar alıcılara ve uygulayıcılara yol gösterici önemli katkılar sunacağ beklenmektedir.Yöntem

$\mathrm{Bu}$ araştırmada nitel araştırma desenlerinden olgu bilim (fenomenolojik) deseni kullanılmıştır. Yıldırım ve Şimşek (2006) nitel araştırmayı; tümevarımcı bir yaklaşımla, olayları ve olguları doğal ortamları içinde betimleme, katılımcıların bakış açılarını anlama ve yansıtma üzerine odaklanan araştırma yöntemi olarak tarif etmektedirler. Olgu bilim deseni ise tüm katılımcıların ortak bir olguyu tecrübe ettiği durumlar olarak tanımlanmaktadır (Creswell, 2012). Bu çalışmada öğretmen adaylarının KPSS olgusuna ilişkin algıları ortaya konulmaya çalışıldığı için olgu bilim deseninin bu araştırmanın amacına uygun olduğu söylenebilir. 


\section{Çalışma Grubu}

Bu çalışmada amaçlı örnekleme yöntemlerinden ölçüt örnekleme kullanılmıştır. Ölçüt örneklemede belirlenen ölçütü karşılayan kişiler örnekleme dâhil edilir (Büyüköztürk, Çakmak, Akgün, Karadeniz ve Demirel, 2012). Araştırmanın amacına daha iyi hizmet edeceği gerekçesiyle, çalışmada ölçüt olarak KPSS'ye yoğun bir şekilde çalışma durumu dikkate alınmıştır.

Araştırmanın çalışma grubunu, 12'si Yüzüncü Yıl Üniversitesi Eğitim Fakültesinin farklı bölümlerinde öğrenim görmekte olan ve 4’ü de fen-edebiyat fakültesi öğrencisi/mezunu olup pedagojik formasyon eğitimi almakta olan toplam 16 öğretmen adayı oluşturmaktadır. Çalışma grubundaki öğretmen adaylarının öğrenim gördükleri bölümler şu şekildedir: Eğitim Fakültesi; Illköğretim Matematik,Sosyalbilgiler,SınıfÖğretmenliği,Orta Öğretim Matematik,Biyoloji,Fizik, Kimya, Edebiyat, İngilizce, Türkçe, Fen Bilgisi,Tarih öğretmenliklerive Fen-Edebiyat Fakültesi; Tarih ve Coğrafya bölümleridir. Öğretmen adaylarının 6'sı kadın, 10’u erkektir.

\section{Verilerin Toplanması}

Çalışmanın verileri yarı yapılandırılmış görüşme tekniğiyle toplanmıştır. Literatür taramasının yanı sıra uzman görüşlerine başvurularak hazırlanan yarı yapılandırılmış görüşme formu araştırmacılar tarafından geliştirilmiştir.Yarı yapılandırılmış görüşme formu 7 adet açık uçlu soru içermektedir.

Veriler öğretmen adaylarının uygun olduğu saatlerde alınan randevular ile uygun bir ortamda yapılan görüşmeler sonucunda elde edilmiş, görüşmeler ses kayıt cihazı ile kayıt altına alınmıştır. Araştırmacılar tarafından gerçekleştirilen görüşmelerin her biri ortalama 1015 dakika sürmüştür. 


\section{Verilerin Analizi}

Görüşmelerde elde edilen ses kayıtları deşifre edilerek doküman haline getirilmiş ve betimsel analiz tekniği kullanılarak veriler analiz edilmiştir. Betimsel analizde amaç, elde edilen bulguların düzenlenmiş ve yorumlanmış bir biçimde okuyucuya sunulmasıdır. $\mathrm{Bu}$ analiz türünde katılımcıların görüşlerini çarpıcı bir şekilde yansıtmak amacıyla sık sık doğrudan alıntılara yer verilir (Yıldırım ve Şimşek, 2006).

Analizlerde her bir görüşmeciye numara verilerek kodlama yapılmıştır. (Eğitim fakültesi öğrencileri, E1, E2.., pedagojik formasyon öğrencileri, F1, F2...). Daha sonra öğretmen adaylarından elde edilen veriler, oluşturulan kategoriler ve temalar çerçevesinde betimsel olarak analiz edilmiş ve ulaşılan bulgulara ilişkin doğrudan alıntılara yer verilmiştir.

\section{Geçerlik ve Güvenirlik}

Araştırmada geçerliği sağlamak için görüşme sorularının belirlenmesinde ve görüşme formunun oluşturulmasında, eğitim bilimleri ve bilimsel araştırma teknikleri alan uzmanlarından görüş alınmıştır. Güvenirlik için de her katılımcının kendi görüşleri arasındaki tutarlılığa bakılmış, ayrıca görüşme kayıtları araştımacılar tarafından ayrı ayrı kodlanarak karşılaştırılmış ve teyit incelemesi yapılmıştır.Bulgular

Araştırmada elde edilen verilerin analizi sonucunda ulaşılan bulgular şu kategoriler altında düzenlenmiştir:(a) Öğretmen adaylarının KPSS'ye yönelik genel bakışı, (b) KPSS'ye alternatif atama modeli önerileri, (c) Öğretmen adaylarının alan sınavına bakışı, (d) Alan sınavına hazırlamada lisans eğitiminin yeterliliği, (e) Eğitim bilimleri testine hazırlamada lisans/pedagojik formasyon eğitiminin yeterliliği, (f) KPSS'nin öğretmen adaylarının öğretmenlik mesleğine yönelik tutumlarına etkisi, (g) KPSS'nin öğretmen adaylarının sosyal yaşantılarına etkisi.

\section{Öğretmen Adaylarının KPSS’yeYönelik Genel Bakışı}


Öğretmen adayları genel olarak, KPSS'nin öğretmen atamada tek başına yeterli ve anlamlı bir ölçüt olmadığı görüşündedirler. Katılımcı adaylar, bir öğretmende bulunması gereken kişisel özelliklerin ve yeterliklerin, salt bilişsel kazanımları ölçmeye dayalı bir sistem olarak nitelendirdikleriKPSS ile sınanarak belirlenmesini çelişkili bir durum olarak ifade etmiş ve eleştirel olarak değerlendirmişlerdir. Bunun yanında KPSS'de çıkan soru sayısının fazlalığı ve kapsamın genişliği öğretmen adaylarının genel olarak eleştiride bulundukları konuların başında gelmektedir. Tüm bunların yanında öğretmen adayları, ülkemiz şartlarında KPSS tarzı bir sınav ile atamaların yapılmasını son tahlilde en tutarlı yol olarak görmektedirler. Nitekim adaylar, ülkemizin sosyo-kültürel yapısı göz önünde bulundurulduğunda KPSS'nin yerine düşünülebilecek hemen hemen tüm modellerin suiistimale açık olduğu konusunda hemfikirdirler. Öğretmen adaylarının KPSS'ye yönelik genel bakışını yansıtan bazı örnek görüşlere aşağıda yer verilmiştir.

“Atamada KPSS'nin yeterli olduğunu düşünmüyorum. Çünkü kişi ders çallşıp KPSS'yi geçmiş olabilir fakat kendini ifade edemeyen pek çok ögrretmen olduğunu düşünüyorum” (E1).

"KPSS tek başına yeterli değil tabi. Öğretmen atamalarında belli kriterlerin olması lazım, fakat bu sınavın bu kadar geniş kapsaml olması öğrencileri bayă̆ı zora sokuyor. Birçok alandan soru soruluyor ve öyle basit sorular değil bunlar... ”(F1).

“... Sinav öncesi klsa bir süre çalışıp atandıktan sonra o bilgileri unutma ihtimaliniz yüksek.Bu da iyi bir ölçüt değil bence. Ama daha iyi bir yolda görünmüyor” (E10).

“... Çok fazla mezun var ve bunları atamak içinde KPSS uygun bir ölçüt. Sonuçta çok fazla aday sınava giriyor. Bunlar arasından bir şekilde seçme ve eleme yapmak lazım. Eleme yapmak içinde en iyi yöntem bu” (E12).

\section{KPSS'ye Alternatif Atama Modeli Önerileri}


$\mathrm{Bu}$ bölümde öğretmen adaylarından öğretmen atamada KPSS yerine önerdiklerideğerlendirme modeline ilişkin görüşleri alınmıştır. Adaylar bu konuda çok farklı görüşler belirtmişlerdir. Öğretmen adayları; mülakat, lisans ortalamasının temel alınması, dönem sonlarında yapılacak olan bir merkezi sınav, stajyerlik uygulamasının değerlendirilmesi gibi öneriler sunmuşlardır. Mezun öğretmen adayları göz önüne alındığında KPSS'ye alternatif olarak geliştirilebilecek atama modeli önerilerinin çoğunun uygulanmasının güçlüğü ve doğabilecek çeşitli sorunlar olduğu açıktır. Toplumumuzun sosyal yapısı dikkate alındığında mülakat tarzı atama modellerinin kafalarda suiistimale ilişkin soru işaretlerine yol açacağı, dönemsel olarak değişen iktidarlarla birlikte değişik kesimlerden tepkiler gelebileceğikuvvetle muhtemeldir. Nitekim katılımcıların bir kısmı bu konuya değinmiş ve yapılabilecek en tutarlı işin içeriğinde bir takım düzenlemeler yapılması kaydıyla KPSS'ye devam edilmesi gerektiğini savunmuştur. Bu bağlamda getirilen önerilerin çoğunluğu, KPSS'de soru çıkan konu/ders sayısının azaltılması yönündedir. Alan sınavının da KPSS'ye dâhil edilmesiyle birlikte öğretmen adayları sınava hazırlık sürecinde yirmiye yakın dersle yüzleşmek durumunda kalmaktadır. Öğretmen adayları bu durumuzorluk ve eziyet olarak nitelendirmekte ve bu konuda karar alıcıların bir an önce bir takım çözüm önerileri getirmelerini istemektedirler.Katılımcıöğretmen adaylarının bu konuya ilişkin belirttiği bazı görüşler şöyledir.

“Bu sınav metodu dışında aklıma başka hiçbir şey gelmiyor. Bence sınav şart. Diğer türlü ne olabilir ki. Ama bu sınavı biraz değiştirmeleri lazım...”(E11.)

"Hani suiistimal edilmeyeceğini bilsek öğretmenler birebir görüşmelerle, mülakatlarla sadece bilgi düzeyinde değil bunları ögrencilere ne kadar aktarabiliyor tarzında olsaydı daha güzel olurdu. Ama şimdi ülkemizde bu tip uygulamalar sorun teşkil eder. Şimdi mülakat dediğimiz zaman aklımıza ne gelir? Dayı gelir, torpil gelir. En azından 
bu tür sınavlar o tip düşünceleri kafamızdan atmamızı sağllyor. En azından çalışan kazanır diyoruz. Ülkemiz bazında düşündüğümüz zaman en iyisi bu sınav” (E12).

\section{Öğretmen Adaylarının Alan Sınavına Bakışı}

Bu konuda öğretmen adaylarının tümü KPSS’ye alan sınavının eklenmesini olumlu karşılamaktadır. Katılımcılar bu uygulama ile adayların kendilerini öğretmenlik yapacakları branşa daha iyi hazırlayacaklarını ve öğrencilerine daha faydalı olacaklarını düşünmektedirler. Katılımcıların bir kısmı ise daha önce KPSS'de çıkmadığından dolayı öğrenciler tarafından gereksiz gibi algılanan alan derslerine bundan böyle daha çok ağırlık verileceği yönünde görüş belirtmektedir. Ayrıca katılımcıların neredeyse tümü alan sınavının geç kalınmış bir uygulama olduğunu, böyle bir uygulamanın baştan beri var olması gerektiğini savunmuşlardır.

Katılımcıların önemli bir kısmı ise alan sınavıyla birlikte KPSS'de zorlandıkları bazı bölümlerin eskiye nazaran sınavdaki etki derecesinin azaldığını belirtmiş ve bu durumu olumlu karşılamıştır. Özellikle sözel bölümlerde okuyan öğrenciler matematiğin, sayısal bölümlerde okuyan öğrenciler ise tarih ve vatandaşlığın KPSS'deki etkisinin azalmasını, olumlu bir uygulama olarak nitelendirmişlerdir. Öğretmen adaylarının alan sınavına yönelik genel bakışını yansıtan bazı örnek görüşlere aşağıda yer verilmiştir.

“KPSS'de alan sinavi yerinde bir uygulama. Sebebi ise alan sinavı gelmeden önce ögrencilerin alan derslerine yönelik olan ilgi ve tutumlartyla alan sinavi geldikten sonraki ilgi ve tutumlarının tamamıyla değişmesi. Daha önce KPSS'de çıkmıyor diye not kaygısıyla 
YYÜ Ĕ̆itim Fakültesi Dergisi (YYU Journal Of EducationFaculty),2017; 14(1):1259-1288,http://efdergi.yyu.edu.tr

http://dx.doi.org/10.23891/efdyyu.2017.45

ISSN:1305-020

geçeyim yeter düşüncesi vardı. Bu şekilde kendi alan derslerini daha iyi ögrenebilme firsatı $\operatorname{dog} d u ”(E 5)$.

“...Hoca dersi anlatıyordu ama öğrenci kendi kendine şunu diyordu "bunun bir fonksiyonu yok, sinavda sorulmuyor." Aşırı derecede göz ardı ediliyordu...” (E9).

“Alan sınavının gelmesi iyi oldu. Üniversite eğitimimize baktı̆̆ımızda ögrrencilerin ne aldı̆̆ı, daha doğrusu ne alamadı̆̆ı ortada. En azından o eksikliği gidermesi açısından iyi. Ama alan sınavını getirip başka bir şeyi çıkarabilirlerdi. Mesela; vatandaşlık, matematik, tarih. Öğrencinin üzerindeki yükü bir nebze olsun azaltabilirlerdi” (E12).

“Alan sınavını gerekli görüyorum. En azından yapamadığımı,, matematik gibi, derslerin KPSS'de ki oranı eskisi kadar çok değil’”(F2).

\section{Alan Sınavına Hazırlamada Lisans Eğitiminin Yeterliği}

Öğretmen adaylarıgenel itibariyle lisans eğitiminin KPSS alan sınavına kısmen hazırladığ1 görüşünedirler. Katılımcıların sadece 2'si alan sınavına hazırlamada lisans eğitiminin yeterli olduğunu savunurken, 10’u lisans eğitiminin alan sınavına kısmen hazırladığı şeklinde görüş bildirmiştir. Katılımcıların 4’ü ise lisans eğitiminin KPSS alan sınavına hazırlamada yetersiz olduğunu öne sürmüştür. Lisans eğitiminin KPSS alan sınavı ile örtüşmemesinin nedenleri olarak; KPSS'nin lisansta alınan derslere göre çok daha kapsamlı olduğu, öğretim elemanlarının müfredatın dışına çıkarak kendi belirledikleri konularda ve istedikleri tarzda ders işlemesi gibi nedenler dile getirilmiştir. Öğretmen adaylarının alan sınavına hazırlamada lisans eğitiminin yeterliğine yönelik genel bakışını yansıtan bazı örnek görüşlere aşağıda yer verilmiştir.

"Tabi ki de lisans eğitimi KPSS ile örtüşmüyor. Bunu çok kesin bir dille söyleyebilirim. Çünkü ben 3. Sinıfta da KPSS'ye girdim. Alan sorularlyla birebir muhatap 
YYÜ Ĕ̆itim Fakültesi Dergisi (YYU Journal Of EducationFaculty),2017; 14(1):1259-1288,http://efdergi.yyu.edu.tr

http://dx.doi.org/10.23891/efdyyu.2017.45

ISSN:1305-020

oldum, biliyorum. Yani mantık olarak birbirinden çok farklı. Kendi çabamızla öğrenmezsek, almış olduğumuz ĕgitim KPSS alan sınavına hazırlamada çok yetersiz” (E4).

“...Zaten almış olduğumuz ĕgitim bizi KPSS alan sınavına tam olarak hazırlamış olsaydı dershane diye bir şey olmayacaktı. Yetersiz kaldığı için şu an dershanelerin ne kadar dolu olduğunu görüyoruz” (E8).

“\% 100 örtüştüğünü söyleyemem. Belki \% 60 veya 70 gibi. Tam bir oranda veremem ama" (E5).

\section{KPSS Eğitim Bilimleri Testine Hazırlamada Lisans/Pedagojik Formasyon}

\section{Eğitiminin Yeterliği}

Öğretmen adaylarının KPSS eğitim bilimleri sınavına hazırlamada lisans/pedagojik formasyon eğitimine ilişkin görüşleri önemli farklılıklar göstermektedir. Katılımcılardan 8'i lisans/pedagojik formasyon eğitimini KPSS eğitim bilimleri sınavına hazırlamada yeterli görürken, 3'ü bu eğitimin yetersiz kaldığını, 5'i ise tamamen olmasa bile kısmen hazırladığı şeklinde görüş belirtmiştir. Öğretmen adayları lisans/pedagojik formasyon eğitiminin KPSS eğitim bilimleri sınavına hazırlamada yetersiz kalmasını; müfredatın öğretim elemanları tarafından tam olarak derse yansıtılmaması, derslere alan dışı hocaların girmesi gibi nedenlere bağlamıştır.

"Ĕ̈itim bilimleri, alan ve genel kültür-genel yeteneğe nazaran KPSS ile daha çok örtüşüyor. \% 85-90 örtüştü̆̆̈̈ kanaatindeyim. Mesela alan sınavında hiç duymadiğımız bir konudan soruyla karşılaşabiliyoruz. Ama eğitim için aynı durum geçerli değil” (E9).

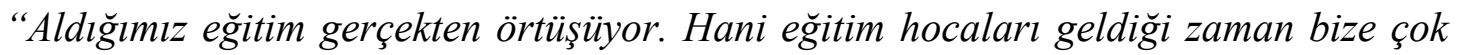
etkili oluyordu. Çünkü alanlarında iyilerdi. Ama iki yıldır alan hocalarımız bizim eğitim derslerimize giriyor. Bu ne kadar mantıklı olabilir ki? Kendi hocalarımız eğitim alanında iyi bir şekilde bilgi veremiyorlar. Çünkü alanları değil”’ (E11). 


\section{KPSS’nin Öğretmen Adaylarının Öğretmenlik Mesleğine Bakışına Etkisi}

Öğretmen adayları genel olarak KPSS'nin yüksek oranda kaygıya neden olduğundan söz ederken, öğretmenlik mesleğine olan tutumlarında herhangi bir değişiklik meydana getirmediği konusunda fikir beyan etmiştir. Katılımcıların bir kısmı ise KPSS'nin öğretmen olarak atanmada en büyük engel olduğunu, bu sınavı geçmenin zorluğunu gördükten sonra öğretmen olarak atanma isteklerinin arttığını dile getirmiştir.

“...Ben KPSS’nin beni bu kadar zorlayacă̆ını düşünmemiştim. Ama yine de ögretmenlik mesleğine olan olumlu tutumumda herhangi bir azalma meydana getirmedi, aksine arttırdı. Çünkü bu kadar zor kazanılan bir şeyin daha çok sevilmesi gerekir” (F2).

"KPSS öğretmenlik mesleğine olan bakışımda herhangi bir değişiklik yapmadı. Hala öğretmenlik yapacă̆ım günü iple çekiyorum” (E3).

“Çok fazla bir etki yapmadı aslında. Şöyle bir kaygı oluşturdu, ülkenin ekonomik şartlarından ötürü acaba atanır mıyım? Atanamaz mıyım? Benim girdiğim yıl iyi alım olacak mı? Gibi bir takım kaygllar oluşturdu tabi” (E5).

\section{KPSS'nin Öğretmen Adaylarının Sosyal Yaşantılarına Etkisi}

Katılımcıların neredeyse tümü KPSS'nin sosyal yaşantılarını az ya da çok olumsuz yönde etkilediğini belirtmiştir. Bazı katılımcılar ise planlı bir çalışma ile KPSS'nin sosyal yaşantıya olumsuz bir şekilde etki etmesinin önüne geçilebileceğini öne sürmüş buna rağmen KPSS'ye gireceğini bilmenin günlük hayattan alınan zevki azalttı̆̆ını, akıllarının bir köşesinde sürekli olarak bu sınavın olduğunu belirtmiştir.

“...Arkadaşlarımla daha az görüşüyorum, ailemle daha az konuşuyorum, yarıyıl tatilinde daha az eve gidecem. Arkadaşlarımla çok vakit geçirdiğimde vicdan azabı 
YYÜ Ĕ̆itim Fakültesi Dergisi (YYU Journal Of EducationFaculty),2017; 14(1):1259-1288,http://efdergi.yyu.edu.tr

http://dx.doi.org/10.23891/efdyyu.2017.45

ISSN:1305-020

yaşıyorum. Ders çalışmış olabilirdim, bir konuyu daha iyi anlamış olabilirdim. Yani oradayken, onlarla sohbet ederken bile aklim orda olabiliyor" (E1).

“...Mesela dün Galatasaray’n maçı vardı. Bi 30 dakikasını izledim daha sonra izlememem gerektiği kanaatine vardım, kalkıp gittim”(E9).

“...Çalışmadığım vakitlerde dışarıdaysam eğer gerçekten insan içten içe bi huzursuzluk hissediyor. Mesela ben geçen sene haftanın her günü dışarı çıkabiliyordum. Ama şimdi öyle değil, kendimi bayă̆ı kısıtladım. KPSS bu konuda beni bayă̆ı etkiledi” (E11).

“...Alan sinavl, genel kültür, genel yetenek, eğitim bilimleri; bunların hepsini yetiştirebilmemiz için günde an az 6-7 saat ders çalışmamız gerekiyor. KPSS olmasa hani arkadaşlarla gezeriz, sinemaya, tiyatroya gideriz ama KPSS bunların hepsini kısitllyor" (E12).

\section{Tartışma, Sonuç ve Öneriler}

Ülkemizde KPSS, sınırlı sayıda ayrılan kadrolara öğretmen atamalarında, fazla sayıdaki başvurular arasından elemeye dayalı seçme ve atama yapmak için yapılmaktadır. $\mathrm{Bu}$ bakımdan öğretmen adaylarının atanabilmesi için tek ölçüt olan KPSS, eğitim sistemimiz ve ülkemizin geleceği açısından büyük önem taşımaktadır (Karataş ve Güleş, 2012). Bu durum KPSS üzerine pek çok çalışmanın yapılmasına neden olmuştur.

KPSS tüm toplumu ilgilendiren yanı ile her kesimin üzerinde konuştuğu ve yorum yaptığı bir uygulamadır. Ancak özellikle öğretmenlerin ne diyeceği, sistem hakkında ne düşündükleri belki de çok daha önemli görülmelidir. $\mathrm{Bu}$ araştırmada öğretmen adaylarının KPSS'ye ilişkin genel görüşleri belirlenmeye çalışılmıştır. Araştırmada ulaşılan genel sonuçlara göre öğretmen adayları, salt bilişsel kazanımları ölçmeye dayalı bir sistem olarak gördükleri KPSS'nin bir öğretmenin sahip olması gereken kişisel özellikleri göz ardı ettiğini, bu açıdan öğretmen atamada tek başına yeterli bir ölçüt olmadığını 
düşünmektedirler.Erdem'e (2015) göre ülkemizde devlet okullarında çalışan öğretmenlerin ilk atamalarının KPSS'de aldıkları puana göre yapılması tek bir faktörü göz önünde bulundurması bakımından belirsizliğe neden olmaktadır. Hotaman'da (2011), sadece bilgiye dayalı sınavlarla nitelikli öğretmen seçmenin mümkün olamayacağını, bu tarz sınavlarla ancak öğrencinin belleğine depoladığı bilginin ölçülebileceğini belirtmiştir. Tüm bunların yanında öğretmen adayları, ülkemiz şartlarında KPSS tarzı bir sınav ile atamaların yapılmasını mevcut şartlarda en makulyöntem olarak görmektedirler.

Araştırma sonucuna göre öğretmen adayların mesleğe atanmada bilişsel bilgilerin yanı sıra mesleki beceriler ve duyuşsal özellikler de dikkate alınmalıdır. Erdem ve Soylu (2013) “Öğretmen Adaylarının KPSS ve Alan Sınavına İlişkin Görüşleri” isimli çalışmalarında konuyla ilgili olarak öğretmen atamalarında teorik ve uygulamalı olmak üzere iki aşamalı bir sınav yapılması gerektiğini belirtmişlerdir. Birinci aşamada KPSS benzeri merkezi bir teorik sınav ile öğretmen adaylarının genel kültür, alan bilgisi ve pedagojik alan bilgisinin sınanması, ikinci aşamada ise, öğretmen eğitimi programlarında yer alan uygulama derslerinin saatlerinin arttırılması ve uzman akademisyenlerin uygulama okullarında bizzat gözlemler yaparak öğretmen adaylarının yeterli olup olmadıklarına karar vermeleri önerilmiştir. Her ne kadar bu türdeki önerilerin öğretmen atamalarında faydalı olabileceği yönünde görüşler olsa da, uygulamalı ve sözlü sınavlara yönelik şüpheler ve güvensizlik düşünüldüğünde bu tür uygulamaların hayata geçmesinintartışmaları beraberinde getireceği söylenebilir. Nitekim 2016 yılı atamalarında uygulanan mülakat sınavına ilişkin çeşitli eleştirel değerlendirmeler içeren raporlar yayınlanmaktadır. $\mathrm{Bu}$ mülakat sınavının, darbe teşebbüsünden terör örgütlerine sempatisi veya iltisakılabilecek adaylara yönelik bir önlem olduğu tartışmalarının yanı sıra, mülakat sınavını geçemeyen adaylar, başta sosyal medya olmak üzere çeşitli platformlarda mülakata ilişkin eleştirel değerlendirme yapmakta, sınavda haksızlıklar yapıldığg, objektif değerlendirme yapılamadığı yorumları yapmaktadır. Nartgün 
(2008), aday öğretmenlerin gözünden Milli Eğitim Bakanlığına bağlı eğitim kurumlarına yapılan öğretmen atamalarını değerlendirdiği çalışmasında, mutlaka bir eleme olacaksa Türkiye koşullarında en sağlıklı elemenin yine sınavla olacağını ve bunun dışındaki elemelerin adil olmayan sonuçları ortaya çıkarma riski taşıdığını belirtmektedir. Bu bağlamda KPSS’nin günümüz şartlarında öğretmen atamada uygun model olduğu, yapılması gerekenin bazı değişiklikler ile KPSS’nin amaca hizmet edecek şekilde daha nitelikli hale getirilmesi olduğu savunulmaktadır.

Araştırmada öğretmen adaylarının KPSS sisteminde bazı düzenlemeler yapılması gerektiğini düşündükleri belirlenmiştir. Soru sayısının fazlalığı ve kapsamın genişliği öğretmen adaylarının genel olarak eleştiride bulundukları konuların başında gelmektedir. $\mathrm{Bu}$ nedenle adaylar özellikle sorumlu oldukları soru ve konu sayısının azaltılması gerektiğini düşünmektedirler. KPSS'deki konu ve soru sayısının fazlalığı öğretmen adaylarını altından kalkılması güç bir durumla baş başa bırakmaktadır. Genel kültür-genel yetenek, alan bilgisi ve eğitim bilimleri testlerinin tümü göz önünde bulundurulduğunda öğretmen adaylarının yirmiye yakın dersten sorumlu tutuldukları görülmektedir. $\mathrm{Bu}$ bağlamda, öğretmen adaylarının genel olarak üzerlerindeki yükün çok fazla olmasından yakındıkları ve sınav kapsamının kısmen daraltılmasının daha doğru olacağı yönündeki görüşlerinin karar alıcı ve uygulamacılar tarafindan dikkate alınmasında yarar vardır.

Araştıma sonucuna göre, KPSS'ye alan sınavının dâhil edilmesi çalışma grubunu oluşturan tüm öğretmen adayları tarafindan olumlu karşılanmıştır. Bu uygulamayla birlikte, konu alanına daha hâkim, daha donanımlı öğretmenlerin seçileceği ve lisans eğitiminin daha değerli bir hale geleceğinin vurgusu yapılmıştır. Bunun yanında lisans eğitiminde alınan derslerin \%50'lik kısmını oluşturan alan bilgisinin daha önce KPSS'ye dâhil edilmemesi öğretmen adayları tarafından bir eksiklik olarak nitelendirilmiştir. Katılımcıların alan sınavına ilişkin olumsuz görüşleri ise genel olarak bu sınavın lisans eğitiminde alınan 
derslerle tam olarak örtüşmediği yönündedir. Bu konudaki eleştiriler KPSS'nin lisansta alınan derslere nazaran çok daha kapsamlı olması ve öğretim elemanlarının müfredatın dışına çıkarak dersi kendi belirledikleri konular üzerinden işlemeleri üzerine yoğunlaşmıştır. Öğretmen adaylarının görüşlerinden yola çıkılarak öğretmen eğitimi programlarının öğretmen adaylarını alan sınavına hazırlama noktasında istenen düzeyde olmadıkları söylenebilir. Demir ve Bütüner (2014) tarafından KPSS alan sınavına ilişkin yapılan çalışmada da benzer sonuçlara ulaşılmış, katılımcılar ortak bir görüşle lisans eğitiminde daha çok ders geçme odaklı, ezbere dayalı bir sistemle eğitim gördüklerinisavunmuş, bunun da KPSS'de adayların aleyhinde olumsuz bir etkiye yol açtı̆̆ını belirtmişlerdir. Bunun yanı sıra katılımcıların ortak görüşüne göre alan sınavına hazırlık yapmak amacıyla öğretmen adaylarının, lisans eğitiminden doğan açığı akademik kitaplar ve dershaneler aracıllı̆ı ile kapatmaya çalıştığının altı çizilmiştir.

Araştırmanın çalışma grubunu oluşturan katılımcıların ortak görüşüne göre KPSS sosyal yaşantıyı olumsuz yönde etkilemektedir. Öğretmen adayları genel itibariyle KPSS ile yüzleşme fikrinin dahi sosyal yaşantılarını olması gereken düzeyde yaşamalarını imkânsız hale getirdiğinden söz etmektedirler. Sezgin ve Duran'ın (2011) yapmış olduğu çalışmada KPSS'nin öğretmen adaylarının çevreyle iletişimlerini ve sosyal ilişkilerini olumsuz yönde etkilediği gibi benzer sonuçlara ulaşılmıştır. Bunun yanında, aynı çalışmada yoğun çalışma temposunun ve sürekli bir şekilde KPSS'yi düşünmenin öğretmen adaylarının sanatsal, sportif ve kültürel faaliyetlere katılımlarını olumsuz yönde etkilediği ortaya çımıştır. Karadeniz ve Demir (2010) tarafindan yapılan çalışmada da benzer sonuçlara ulaşıldığı görülmektedir. $\mathrm{Bu}$ çalışmada, öğretmen adaylarının boş vakitlerinin tümünü KPSS’ye çalışmakla geçirmelerinden dolayı sosyal, sportif ve kültürel faaliyetlere zaman ayıramadıkları ve kendilerini boşlukta hissettikleri ifade edilmiştir. 
Araştırmada ulaşılan ve yukarıda tartışılan sonuçlar doğrultusunda karar alıcılar, uygulayıcılar ve araştırmacılara dönük aşağıdaki öneriler getirilmiştir:

1. Genel kültür-genel yetenek, alan bilgisi ve eğitim bilimleri testlerinin tümü göz önüne alındığında öğretmen adayları, KPSS'deyirmiye yakın dersten sorumlu tutulmaktadır. Bu durum öğretmen adayları tarafından altından kalkılması zor bir durum olarak nitelendirilmektedir. Öğretmen adayları KPSS’nin kapsamının daraltılması gerektiği konusunda görüş birliği içerisindedir. Bu bağlamda genel kültür ve genel yetenek sınavları KPSS'den çıkarılarak ya da oranı azaltılarak öğretmen adayları daha çok alan bilgisi ve eğitim bilimleri testlerinden sınava tabi tutulmalı, üzerlerindeki yük bir nebze hafifletilmelidir.

2. Öğretmen adayları öğretmenlik uygulaması dersinde okullarda ders anlatmaya yönelik staj uygulamasının önemi hakkında ortak görüşe sahip olmasına rağmen KPSS'den dolayı yaşamış oldukları stres ve bu sınava uzun vakitler harcamaları nedeniyle staj uygulamasından istedikleri verimi almadıklarını belirtmektedirler. Öğretmenlik mesleğine hazırlanmada hayati öneme sahip olan staj uygulamasının daha verimli bir şekilde gerçekleşmesi ve vakitlerinin çoğunu sınava hazırlanma ile harcayan öğretmen adaylarının bu konudaki mağduriyetinin giderilmesi bakımından öğretmenlik uygulaması dersi 3. sınıf programına veya hizmetiçi eğitim programına dâhil edilebilir.

3. Öğretmen atama uygulamalarına ilişkin yapılacak başka çalışmalarda KPSS puanı ve mülakat sonuçları arasındaki korelasyon incelenebilir.

4. KPSS'nin ülkemiz açısından bu denli büyük öneme sahip olması bu konu üzerine gelecekte yapılacak olan çalışmalarında ülkemizin geleceği açısından önemli 
YYÜ Eğitim Fakültesi Dergisi (YYU Journal Of EducationFaculty),2017; 14(1):1259-1288, http://efdergi.yyu.edu.tr

http://dx.doi.org/10.23891/efdyyu.2017.45

ISSN:1305-020

hizmetlerde bulunacağı gerçeğini de beraberinde getirmektedir. Benzer bir çalışma

KPSS-A grubu kadrolar için yapılan sınavlara yönelik olarak gerçekleştirilebilir.

\section{Makalenin Bilimdeki Konumu (Yeri)}

\section{Eğitim Bilimleri Alanı}

\section{Makalenin Bilimdeki Özgünlüğü}

Ülkemizde KPSS, sınırlı sayıda ayrılan kadrolara öğretmen atamalarında, fazla sayıdaki başvurular arasından elemeye dayalı seçme ve atama yapmak için yapılmaktadır. $\mathrm{Bu}$ bakımdan öğretmen adaylarının atanabilmesi için bir ölçüt olan KPSS, eğitim sistemimiz ve ülkemizin geleceği açısından büyük önem taşımaktadır KPSS'nin nitelikli öğretmen seçmede yeterli ve amaca uygun bir seçme uygulaması olup olmadığı sorunsalı gündemdeki yerini korumaktadır. Bu bağlamda KPSS üzerine yapılacak çalışmaların, bu sınavın ve öğretmen seçme sisteminin daha işlevsel hale gelmesinde özellikle karar alıcılara ve uygulayıcılara yol gösterici önemli katkılar sunacağı beklenmektedir.

\section{Kaynakça}

Adıgüzel, A. (2008). Eğitim fakültelerinde öğretmen eğitimi program standartlarının gerçekleşme düzeyi. Yayınlanmamış Doktora Tezi. Eskişehir: Anadolu Üniversitesi Ĕ̆itim Bilimleri Enstitüsü.

Akdemir, A. S. (2013). Türkiye'de öğretmen yetiştirme programlarının tarihçesi ve sorunlar1. Electronic TurkishStudies, 8(12), 15-28.

Büyüköztürk, Ş., Çakmak Kılıç, E., Akgün, Ö.E., Karadeniz, Ş. ve Demirel F. (2012). Bilimsel Araştırma Yöntemleri. Ankara: Pegem A Yayıncılık . 
YYÜ Ĕ̆itim Fakültesi Dergisi (YYU Journal Of EducationFaculty),2017; 14(1):1259-1288,http://efdergi.yyu.edu.tr

http://dx.doi.org/10.23891/efdyyu.2017.45

ISSN:1305-020

Creswell,

$\mathrm{J}$.

W.

(2012). Qualitativeinquiryandresearchdesign:

Choosingamongfiveapproaches.ThousandOaks: Sage.

Çapa, Y., Çil, N. (2000). Öğretmen adaylarının öğretmenlik mesleğine yönelik tutumlarının farklı değişkenler açısından incelenmesi. Hacettepe Üniversitesi Eğitim Fakültesi Dergisi, 18(18), 69-73.

Demir, S. B., Bütüner, K. (2014). Sosyal bilgiler öğretmen adaylarının alan sınavına yönelik görüşlerinin incelenmesi. Mersin Üniversitesi Eğitim Fakültesi Dergisi, 10(2), 113-128.

Eraslan, L. (2006). Öğretmenlik mesleğine girişte kamu personeli seçme sınavı (KPSS) yönteminin değerlendirilmesi. International Journal of Human Sciences, 1(1), 1-31.

Erdem, A. R. (2013). Öğretmen Yetiştirmenin Bugünü ve Geleceği: Sorunlar ve ÇözümÖnerileri, Ankara: Anı Yayıncılık

Erdem, A. R. (2015). Türkiye'deki öğretmen yetiştirmenin [A], [B], [Ç]'si. Journal of TeacherEducationandEducators, 4(1), 16-38.

Erdem, E., Soylu, Y. (2013). Öğretmen adaylarının KPSS ve alan sınavına ilişkin görüşleri. Çankırı Karatekin Üniversitesi Sosyal Bilimler Enstitüsü Dergisi, 4(1), 223236.

Gedikoğlu, T. (2005). Avrupa birliği sürecinde Türk eğitim sistemi: sorunlar ve çözüm önerileri. Mersin Üniversitesi Eğitim Fakültesi Dergisi, 1(1), 66-80.

Hotaman, D. (2011). Eğitim fakülteleri kendi öğrencilerini seçebilir mi. Kuramsal Ĕ̆itimbilim Dergisi, 4(1), 126-136. 
http://www.memurlar.net/haber/535965/ adresinden 17.10.2015 tarihinde erişilmiştir.

Milli Eğitim Temel Kanunu [METK](1973). Kanun numarası: 1739. Resmi Gazete, 24, 14574.

Karaca, E. (2008). Eğitimde kalite arayışları ve eğitim fakültelerinin yeniden yapılandırılması. Dumlupınar Üniversitesi Sosyal Bilimler Dergisi, 21, 61-80.

Karadeniz, Y., Demir, S. B. (2010). Sözleşmeli öğretmenlik uygulamasının değerlendirilmesi. Ondokuz Mayıs Üniversitesi Ĕ̆itim Fakültesi Dergisi, 29(2), 55-77.

Karataş, S.,Güleş, H. (2013). Öğretmen atamalarında esas alınan merkezi sınavın (KPSS) öğretmen adaylarının görüşlerine göre değerlendirilmesi. Kuramsal Eğitimbilim Dergisi, 6(1), 102-119.

Kavcar, C. (2002). Cumhuriyet döneminde dal öğretmeni yetiştirme. Ankara Üniversitesi Eğitim Bilimleri Fakültesi Dergisi, 35(1-2), 1-14.

Nartgün, Ş. S. (2008). Aday öğretmenlerin gözüyle Milli Eğitim Bakanlığına bağlı eğitim kurumlarına öğretmen atama esasları. Abant İzzet Baysal Üniversitesi Eğitim Fakültesi Dergisi, 8(2), 47-58.

Öztürk, C. (1999). Cumhuriyet Döneminde Öğretmen Yetiştirme. 75 Yllda Eğitim. İstanbul: Tarih Vakfı Yayınları

Sezgin, F., Duran, E. (2011). Kamu Personeli Seçme Sınavı'nın (KPSS) öğretmen adaylarının akademik ve sosyal yaşantılarına yansımaları. Türkiye Sosyal Araştırmalar Dergisi [TurkishJournal of SocialResearch], 15(3), 9-22. 
YYÜ Ĕ̆itim Fakültesi Dergisi (YYU Journal Of EducationFaculty),2017; 14(1):1259-1288,http://efdergi.yyu.edu.tr http://dx.doi.org/10.23891/efdyyu.2017.45

ISSN:1305-020

Sünbül, A. M. (1996). Öğretmen niteliği ve öğretimdeki rolleri. Kuram ve Uygulamada Eğitim Yönetimi, 2(4), 597-607.

Şişman, M. (2011). Eğitim Bilimine Giriş. Ankara: Pegem Akademi.

Taşdan, M. (2011). Öğretmen yetiştirme alanındaki uygulamalar ve gelişmeler (Editör: Memduhoğlu, H. B., Yılmaz, K.) Eğitim bilimine giriş içinde. Ankara: Pegem Akademi.

Unat, F. R. (1964). Türkiye eğitim sisteminin gelişmesine tarihi bir bakış. Ankara: Milli Eğitim Basımevi

Yıldırım, A., Şimşek, H. (2006). Sosyal bilimlerde nitel araştırma yöntemleri. Ankara: Seçkin Yayıncılık.

Yüksek Öğretim Kurulu [YÖK] (2007). Eğitim Fakültesi Öğretmen Yetiştirme Lisans Programlar1.

Yüksel. S. (2004). Öğretmen atamalarında merkezi sınav uygulamasının (KPSS)değerlendirilmesi. XIII. Ulusal Eğitim Bilimleri Kurultayında sunulmuş sözlü bildiri, İnönü Üniversitesi, Malatya, Türkiye. http://www.pegem.net/dosyalar/ dokuman/118.pdf adresinden alınmıştır.

\section{Extended Abstract}

\section{Problem}


Teacher training is a very comprehensive field consisting of many different dimensions such as selection of teacher candidates, pre-service training, internship practices and in-service training (Kavcar, 2002). When we consider these dimensions in succession, it is necessary for the selection of teacher candidates to be first step in the process. There are criticisms that the central examination system used in the selection of teacher candidates in Turkey is insufficient in terms of measuring the personal competences of candidates.

In past years, candidates graduating from teacher training programs in Turkey have been appointed in an unconditional manner, not based on merit or qualifications. In September 2015, The Ministry of Education announced 37.000 available teaching positions and received 161.836 applications. The number of applications in all fields is well above the number of open positions. Previously, several methods were applied in the selection process of teacher candidates. One is the Civil Servant Selection Examination (CSSE) and it is currently being used.

The debate continues on CSSE which is the only one of method along with interviewing used today for selecting teachers. The issue at the heart of these debates is the question of whether CSSE functions adequately in the selection of qualified teachers and whether or not it is an appropriate choice. When we consider the positive influence that a qualified teacher has on students and society, we can understand that CSSE is a test with vital importance forTurkey. In this context, it is expected that the studies to be made on CSSE will enhance the examination. The improved CSSE mayenable administrators to hire better qualified teachers who ultimately play a leading role in the educating of individuals to meet the requirements of the present age.

\section{Purpose of the Study}


The aim of this study is to reveal the pre-service teachers' opinions on Civil Servant Selection Examination (CSSE) and field examination.

\section{Method}

In this study, criteria sampling has been used which is a purposeful sampling method. The study has been conducted with total of 16 pre-service teachers. 12 of whom were students at the YüzüncüYıl University Education Faculty and the other 4 participants were students/bachelor from Faculty of Science and Faculty of Humanities and were attending the pedagogical formation certificate program. Six of the participants were female and others were male. In the study, phenomenological design was used which is a qualitative research design. It is believed that the phenomenological design is appropriate for the purpose of this research because the pre-service teachers' perceptions of CSSE occurrences were tried to be revealed. The data of the study were collected by semi-structured interview technique. The interview form has been developed by the researchers by referring to expert opinions and by searching the literature. The interview form consists of 7 open ended questions. The voice recordings obtained in the interviews were documented and analyzed by using descriptive analysis technique. Direct citation was often used in order to reflect the views of the participants strikingly.

\section{Findings and Discussions}

In general, teacher candidates do not view the CSSE as being a sufficient and meaningful sole criterion in teacher appointment. Participant candidates expressed the contradiction in the determination of the personal qualities and competences that teachers possess by testing it with CSSE, which is based on measuring cognitive gains alone.

Teacher candidates pointed out different opinions about the evaluation model they proposed instead of CSSE in appointing teachers. They proposed a combination of 
interviews, grade point average, a central examination to be done at the end of each semester, and evaluation of internships.

All teacher candidates agreed on the additional requirement of taking a subject specific test related to their field as a part of CSSE. Participants think that candidates will be better prepared to teach their subject and they will be more useful to their students. The majority of the participants found the subject field test more beneficial and liked that the general exam would have less influence on their overall score.

Teacher candidates believe that undergraduate education is partially preparing them for the subject field test in CSSE exam. They have generally expressed the opinion that CSSE does not cause any change in attitudes towards the teaching profession but does cause them high levels of stress. Almost all of the participants noted that CSSE influenced their social life more or less negatively.

\section{Conclusions and Recommendations}

According to the general results reached in the research, the teacher candidates think that CSSE, which they see as a system based only on measuring cognitive gains, ignores the personal characteristics that a teacher should have and in this respect, they think that it is not a sufficient criterion in the teacher appointment alone. In addition to cognitive knowledge, professional skills and affective characteristics must be taken into consideration when filling teacher positions.

According to the findings of the study, the inclusion of the field exam to CSSE was welcomed by all of the participants. Pre-service teachers think that CSSE is inadequate to measure the teaching skills. Nevertheless, the pre-service teachers regard the CSSE examination as the most reasonable method in Turkey's conditions. 
Based on the conclusions reached in the research and discussed above, the following suggestions have been made for administrators and researchers:

1. Teacher candidates should be subjected to more tests from field knowledge and educational sciences tests and the burden on them should be lightened to some extent by reducing or eliminating general culture and general aptitude exams from CSSE.

2. The internship which has a significant impact should be included in the 3rd year curriculum in order to make the teaching profession more efficient and to eliminate the victimization of the teacher candidates who spend most of their time preparing for the examination.

3. Similar studies can be carried out for examinations made for CSSE group A staff. 